Article

\title{
Anaerobic Mineralization of Recirculating Aquaculture Drum Screen Effluent for Use as a Naturally-Derived Nutrient Solution in Hydroponic Cropping Systems
}

\author{
Joseph Tetreault ${ }^{1,2, *}$, Rachel Fogle ${ }^{3}$ and Todd Guerdat ${ }^{1,4}$ \\ 1 Department of Agriculture, Nutrition, and Food Systems, University of New Hampshire, \\ Durham, NH 03824, USA; todd.guerdat@usda.gov \\ 2 Environmental Science Program, Harrisburg University of Science and Technology, \\ Harrisburg, PA 17101, USA \\ 3 Integrative Sciences Program, Harrisburg University of Science and Technology, Harrisburg, PA 17101, USA; \\ rfogle@harrisburgu.edu \\ 4 Natural Resources Conservation Services, United States Department of Agriculture, Epping, NH 03042, USA \\ * Correspondence: jtetreault@harrisburgu.edu
}

check for

updates

Citation: Tetreault, J.; Fogle, R.;

Guerdat, T. Anaerobic Mineralization

of Recirculating Aquaculture Drum

Screen Effluent for Use as a

Naturally-Derived Nutrient Solution in Hydroponic Cropping Systems.

Conservation 2021, 1, 151-167.

https://doi.org/10.3390/

conservation 1030013

Academic Editor: Antoni Margalida

Received: 22 May 2021

Accepted: 16 June 2021

Published: 1 July 2021

Publisher's Note: MDPI stays neutral with regard to jurisdictional claims in published maps and institutional affiliations.

Copyright: (c) 2021 by the authors. Licensee MDPI, Basel, Switzerland. This article is an open access article distributed under the terms and conditions of the Creative Commons Attribution (CC BY) license (https:// creativecommons.org/licenses/by/ $4.0 /)$.

\begin{abstract}
Operation and effluent treatment costs are limiting factors for the success of recirculating aquaculture systems (RAS) in meeting seafood demand in the United States. Adopting a capture-andreuse waste management model similar to terrestrial agriculture farmers would allow RAS farmers to monetize effluent and offset production costs. The moisture content and nutrient profile of RAS effluent makes it a potential option for use as a hydroponic fertilizer. Treatment of RAS waste is needed to mineralize particulate-bound nutrients before becoming a viable hydroponic nutrient solution. Anaerobic treatment (AT), a method used by municipal and agricultural waste treatment facilities to reduce total solids, has been shown to successfully mineralize particulate-bound nutrients from RAS effluent. Continuously mixed anaerobic batch bioreactors were used to evaluate the degree to which AT may mineralize particulate-bound nutrients in solid RAS waste. Concentrations of twelve different macro- and micro-nutrients were analyzed in the waste before and after treatment. Effluent samples were analyzed to determine the fraction of each nutrient in the solid and aqueous forms. This study showed that AT is an effective method to mineralize particulate-bound nutrients in RAS effluent and the mineralization rate data may be used to design a pilot-scaled flow-through RAS effluent treatment system.
\end{abstract}

Keywords: nutrient resource management; aquaculture; anaerobic treatment; aquaponics; circular nutrient economy; hydroponics

\section{Introduction}

Land based recirculating aquaculture systems (RAS) are a promising option to enhance the aquaculture industry and provide fresh seafood in non-coastal regions due to their location independence and water conservation [1,2]. A well-maintained RAS typically uses from 90-99\% less water than conventional aquaculture systems [3] (pp. 2-25). The rapid removal and transformation of waste allows high rates of water reuse, setting RAS apart from other forms of aquaculture [3] (pp. 2-25). However, operating costs associated with treating and discharging captured waste effluent contribute to the prevention of RAS from achieving greater commercial success [4-7]. Adopting a capture-and-reuse waste management system similar to that utilized by terrestrial animal agriculture farmers would allow RAS farmers to turn effluent into a commodity. The high liquid content of RAS effluent provides the potential for reuse in hydroponic plant production $[8,9]$. Not only can waste-to-energy practices provide a sustainable pathway, but also, improved technologies on waste valorization may result in the production of high-value co-products and overall environmental benefits such as reduction of greenhouse gas (GHG) emissions [10-13]. The 
development of a naturally-derived nutrient solution from RAS effluent would benefit both aquaculture and hydroponic industries by offsetting operating costs associated with RAS waste management while developing a circular nutrient economy that is not reliant on finite reserves of mined minerals [14-16].

Goddek et al. [17] (pp. 247-266) states that additional treatment is needed to remove organic matter, reduce solids content, and mineralize particulate-bound nutrients before RAS effluent can be utilized as an effective hydroponic nutrient solution. Anaerobic treatment (AT) is a commonly used process for agricultural and municipal wastewater treatment where natural metabolic processes of bacteria are used to breakdown organic matter [18]. Obligate anaerobes grow in the absence of oxygen and oxidize organic matter in a four-stage process $[19,20]$. Hydrolysis is the first stage of treatment and utilizes water molecules and enzymes to separate chemically bonded complex organic matter such as proteins, lipids, and carbohydrates. These complex components are hydrolyzed into simpler monomer and dimer compounds including amino acids, sugars, and short and long chain fatty acids [21]. Acidogenesis is the second stage and creates volatile fatty acids (VFA) and intermediate products of butyrate and propionate through fermentation of sugars and simple monomers created during hydrolysis [22]. The third stage of the process is acetogenesis, which occurs after VFA formation during fermentation and is the reduction of intermediate fermentation products into acetate, hydrogen, and carbonate [22]. Methanogenesis is the fourth and final stage of anaerobic digestion and results in the oxidization of acetate, hydrogen, and carbonate to methane $\left(\mathrm{CH}_{4}\right)$ and hydrogen gas $\left(\mathrm{H}_{2}\right)$. The end-product is a digestate comprised of inert solids, a treated effluent with a reduced solid and organic masses, and $\mathrm{CH}_{4}, \mathrm{H}_{2}$, and carbon dioxide $\left(\mathrm{CO}_{2}\right)$ gases that can be collected and sold or used to produce power [22].

Several studies have begun to characterize the AT of RAS effluent [23-26]. Out of the published literature, none assessed mineralization across an array of plant essential nutrients, tracked solids reduction and oxidative reduction potential (ORP) at multiple time points throughout the treatment process, measured TOC reduction, reported data in terms of nutrient ratios required for hydroponic crop production, and used unconcentrated effluent that would be commensurate with standard RAS farming conditions in the same study period [23-26]. The primary objective of this research was to characterize the degree of nutrient mineralization and solids reduction in effluent from the co-production of Nile tilapia (Oreochromis niloticus) and butterhead lettuce (Lactuca sativa var. capitata) achieved by AT in lab-scaled batch reactors. Secondary goals included comparing the nutrient profile of the treated effluent with recommended hydroponic nutrient needs and identifying optimization opportunities to refine the AT process for nutrient mineralization. The anaerobic treatment successfully reduced TOC and TSS concentrations and increased the percent of the total nutrient mass dissolved into the treated solution.

\section{Materials and Methods}

This project was conducted using effluent from the University of New Hampshire (UNH) Kingman Farm Recirculating Aquaponic Research Greenhouses (KFRAG) located in Madbury, NH, USA. The UNH KFRAG systems were operated for at least one year prior to collecting samples for analysis. The facility was operated with feeding and waste production rates commensurate with previously established RAS production standards $[27,28]$. Fish were fed using a propriety feed rate calculator, with the amount of feed based on average fish weight, that was developed by a RAS tilapia farmer to grow fish from fry to a $680 \mathrm{~g}$ harvest mass in 38 weeks. Operation during this time occurred without any prominent changes to the system that would influence data analysis.

\subsection{Aquaponic Facility Description}

The recirculating aquaponic system was housed in an $11.0 \mathrm{~m} \times 14.6 \mathrm{~m}$ high tunnel greenhouse (Nor'Easter Series, Rimol Greenhouse Systems, Hookset, NH, USA) and was covered using polycarbonate. The recirculating systems consisted of a $3000 \mathrm{~L}$ fish culture 
tank, a rotary drum screen filter (PR Aqua model RFM2014) fitted with 54 micron screens, a $1300 \mathrm{~L}$ mixed media bed bioreactor (MBBR) used for nitrification, a $200 \mathrm{~L}$ pumping reservoir, a $300 \mathrm{~L}$ standpipe well, and three $12.6 \mathrm{~m}^{2}$ deep water raft (DWR) hydroponic growing tables used for hydroponic lettuce production. The combined system volume was 15,000 L. The only nutrient supplementations made to the system were daily additions of potassium carbonate $\left(\mathrm{K}_{2} \mathrm{CO}_{3}\right)$ to maintain system alkalinity at $40 \mathrm{mg} / \mathrm{L} \mathrm{CaCO}$ for biofilter management and a chelated diethylemetriamine pentaacetic acid (DTPA) iron (III) salt that was added as needed to ensure that sufficient iron $(\mathrm{Fe})$ concentrations, $2.0 \mathrm{mg} / \mathrm{L}$, were met in the system for optimum lettuce growth [29].

Tilapia were stocked at $36 \mathrm{~kg}$ per $\mathrm{m}^{3}$ and fed $3 \mathrm{~mm}$ floating feed (Finfish Silver, $40 \%$ protein, 10\% lipid, Zeigler Bros. Inc., Gardner, PA, USA). The fish were fed 1300 g/day and a constant biomass approach to maintain a consistent feed rate was used. The total fish biomass in the culture tanks was measured bi-weekly and the number of fish in the culture tank was adjusted to ensure that $1300 \mathrm{~g}$ of feed each day would provide optimum fish growth rates per Delong et al. [28].

\subsection{Drum Screen Effluent Collection, Effluent and Feed Analysis, and Nutrient Characterization}

A 200 L composite sample of effluent was collected from the rotary drum screen filter over $72 \mathrm{~h}$ and captured multiple feed cycles over a sufficient period for fish to eat feed and excrete waste multiple times. The collected effluent was aerated to preserve nitrogen (N) and prevent microbial denitrification during the collection period. The effluent was well mixed and then immediately sampled and analyzed. The effluent was filtered into particulate and aqueous fractions before any analysis using 1.5-micron filters. Analysis of TSS was conducted at the UNH Agricultural Engineering Laboratory (Method 2540D, APHA, [30] (pp. 2-70, 2-71). A Fisher Scientific Accumet AB250 (Waltham, MA, USA) was used for $\mathrm{pH}$ measurements.

A nutrient profile of the feed and a hydroponic nutrient profile of the effluent was determined using a commercial hydroponic fertilizer laboratory service (JR Peters Laboratory, Allentown, PA, USA). Feed particles and the separated particulate and aqueous fractions of the effluent were analyzed for six macro-nutrients, including $\mathrm{N}$, phosphorus $(\mathrm{P})$, potassium $(\mathrm{K})$, calcium $(\mathrm{Ca})$, magnesium $(\mathrm{Mg})$, and sulfur $(\mathrm{S})$, as well as six micro-nutrients, including $\mathrm{Fe}$, manganese $(\mathrm{Mn})$, copper $(\mathrm{Cu})$, zinc $(\mathrm{Zn})$, sodium $(\mathrm{Na})$, and aluminum $(\mathrm{Al})$. The particulates analyzed were captured on the filters used to separate the particulate and aqueous effluent fractions. Filters were dried at $110^{\circ} \mathrm{C}$ for a minimum of $72 \mathrm{~h}$ before being ground and sent for analysis. Filter blanks were also dried and ground to ensure that no extraneous nutrients were considered in the experimental analysis. Solid nutrient analysis was conducted using combustion and an organic elemental analyzer. The filtrate consisted of the aqueous fraction of the filtered effluent and was analyzed using inductively coupled plasma atomic emission spectrometry. The concentration of each nutrient in the aqueous fraction of the effluent was reported in $\mathrm{mg} / \mathrm{L}$. Nutrients dissolved in the aqueous fraction of the filtered effluent were assumed to be plant available, as previously published research has demonstrated effective crop growth using mineralized nutrients from RAS effluent [8,9] Plant availability of each nutrient was determined by the percent of its total mass in the aqueous fraction. The OC and total nitrogen (TN) analyses were conducted by the United States Forest Service's Northeastern Forest Science Application Lab (Durham, NH, USA). Particulate and aqueous samples were prepared in the same manner as the samples used in the hydroponic nutrient profile analysis. Particulate samples of the effluent were analyzed for OC and TN using combustion. The percent of $\mathrm{C}$ and $\mathrm{N}$ that made up the total mass of the particulates was reported. Dissolved organic carbon (DOC) in the aqueous sample was analyzed using high temperature oxidation (HTO) and total dissolved nitrogen (TDN) was analyzed using HTO with chemiluminescent $\mathrm{N}$ detection as described in Merriam et al. [31], with a Shimadzu TOC-5000 High Temperature Catalytic Oxidization (HTCO) carbon analyzer (Shimadzu Scientific Instruments, Inc., Columbia, MD, USA) and an Antek 720C 
chemiluminescent $\mathrm{N}$ detector (Antek Instruments, Inc., Houston, TX, USA). The DOC and TDN concentration in the aqueous fraction of the filtered effluent were reported in $\mathrm{mg} / \mathrm{L}$.

The drum screen effluent contained all RAS waste greater than 54 microns. This included nutrients in aqueous and particulate forms. The total nutrient concentration was determined as a means for characterizing and normalizing the total mass of each nutrient in the reactor, regardless of form, based on total nutrient mass and reactor effluent volume. The total concentration of each nutrient, in $\mathrm{mg} / \mathrm{L}$, was calculated by totaling the particulate and aqueous nutrient masses as a function of reactor effluent volume. The percent of the total concentration of each nutrient in the aqueous and particulate fractions was used to determine plant availability and provide a comparison to the nutrient profile of a commercial hydroponic fertilizer. Nutrients dissolved in the aqueous fraction of the effluent were assumed to be plant available.

Particulate nutrient mass fraction results from the analysis for N, P, K, Ca, and $\mathrm{Mg}$ were reported as a percentage of the TSS mass and were calculated using the following equation:

$$
\mathrm{M}_{\text {solids }, \%}=[\mathrm{TSS}] \times \mathrm{C}_{\%}
$$

where $\mathrm{M}_{\text {solids, } \%}$ is the nutrient mass for the entire reactor volume (as $\mathrm{mg} / \mathrm{L}$ ) for nutrients reported as \% of TSS, TSS is the concentration of the TSS of the drum screen effluent in the reactor $(\mathrm{mg} / \mathrm{L})$, and $\mathrm{C}_{\%}$ is the mass of the nutrient as a percentage of the reactor TSS.

Particulate nutrient mass fraction for $\mathrm{S}, \mathrm{Fe}, \mathrm{Mn}, \mathrm{Cu}, \mathrm{Zn}, \mathrm{Na}$, and $\mathrm{Al}$ were reported as $\mathrm{mg}$ nutrient $/ \mathrm{kg}$ TSS, and the associated mass was calculated using the following equation:

$$
\mathrm{M}_{\text {solids }, \mathrm{f}}=\frac{[\mathrm{TSS}] \times \mathrm{C}_{\mathrm{f}}}{\mathrm{V}_{\text {effluent }}}
$$

where $M_{\text {solids, }}$ is the nutrient mass for the entire reactor volume (as $\mathrm{mg} / \mathrm{L}$ ) for nutrient mass fractions reported as mg nutrient/ $\mathrm{kg}$ TSS, TSS is the concentration of TSS in the reactor wastewater $(\mathrm{kg} / \mathrm{L}), \mathrm{C}_{\mathrm{f}}$ is the nutrient mass fraction of TSS reported as mg nutrient $/ \mathrm{kg}$ TSS, and $V_{\text {effluent }}$ is the volume of the drum screen effluent in the reactor $(\mathrm{L})$.

\subsection{Continuously Mixed Batch Reactor Design}

Anaerobic treatment of the collected effluent was conducted using 20 L high density polyethylene (HDPE) anaerobic reactors (Figure 1). The effluent was continuously mixed using an externally mounted recirculating pump (Danner Supreme Mag-Drive 190 GPH, New York, NY, USA) that pumped from the bottom center of the reactor and recirculated through a manifold with three equally spaced $0.64 \mathrm{~cm}$ outlets angled to ensure maximum circulation. A one-way check valve with a 0.023 bar cracking pressure was mounted on the lid of each reactor to allow gas ventilation (e.g., $\mathrm{CH}_{4}$ and $\mathrm{CO}_{2}$ ) as needed. A $1.91 \mathrm{~cm}$ port was positioned $2.54 \mathrm{~cm}$ from the base of the reactor to allow sampling. Two $1.91 \mathrm{~cm}$ ports for nitrogen gas venting were installed in the reactor lids to allow nitrogen purging of the headspace during sampling to prevent oxygen infiltration.

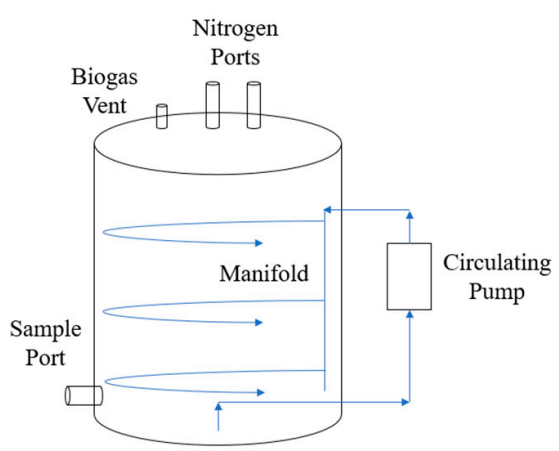

Figure 1. Reactor schematic. Effluent was circulated using a small inline pump and removed from the center of the reactor vessel and recirculated using a vertical manifold. 


\subsection{Experimental Design}

One anaerobic microbial treatment was evaluated in this study. An abiotic control was used to provide a reference for microbial and physical effects of treatment. The treatment and control used the same batch of drum screen effluent, and the anaerobic treatment and abiotic controls were each conducted in triplicate at the same time. The anaerobic treatment was not inoculated and used only endogenous microbes present at the time of collection. The abiotic control was dosed with $0.05 \%$ sodium azide $\left(\mathrm{NaN}_{3}\right)$ to inhibit microbial growth and biological activity [32]. Dissolved oxygen (DO) concentrations, ORP, $\mathrm{TN}$ concentrations, and total S concentrations were monitored in both the AT reactors and abiotic controls to ensure proper functioning of the reactor systems.

The experiment was conducted for 15 days in correspondence to previously established retention times for RAS effluent treatment [24]. Final analyses for TOC, N, P, K, Ca, $\mathrm{Mg}, \mathrm{S}, \mathrm{Fe}, \mathrm{Mn}, \mathrm{Cu}$, and $\mathrm{Zn}$ were conducted after stabilization to determine the change in the plant availability of each nutrient after AT. Data collected throughout the study were compared with Jack's Hydroponic Solution (jrpeters.com, accessed on 15 October 2020), a commercially available fertilizer mix, to provide a reference for relative nutrient availability and identify nutrients where supplementation would be required.

\subsection{Reactor Operation and Sample Analysis}

Each reactor was filled with $15 \mathrm{~L}$ of drum screen effluent. Sample volumes of $50 \mathrm{~mL}$ were collected from each of the three AT reactors and abiotic controls every $48 \mathrm{~h}$. Sample analysis included temperature, DO, pH, TSS, and ORP. Samples were collected in $150 \mathrm{~mL}$ beakers from the reactor sample ports. Prior to sampling, $\mathrm{N}_{2}$ gas was administered into the system immediately before the nitrogen ports were opened to prevent oxygen infiltration. The sample port was only opened while the $\mathrm{N}_{2}$ gas was being administered and was always closed prior to stopping gas flow. Collection beakers were held at a 45-degree angle to prevent the sample from splashing during collection. Samples were analyzed immediately to prevent atmospheric interference. A Hach (Loveland, CO, USA) IntelliCAL ORP-REDOX probe was used for ORP measurement and a Hach HQ 40D was used for DO measurements. Temperature, $\mathrm{DO}$, and $\mathrm{pH}$ were monitored to ensure ideal AT operating parameters, while stabilization in ORP and TSS was used to determine treatment completion. Reactors were operated at ambient temperatures and reactor $\mathrm{pH}$ was adjusted using $1 \mathrm{M}$ hydrochloric acid $(\mathrm{HCl})$ when the $\mathrm{pH}$ measured above 8 to maintain an appropriate environment for anaerobic microbes [33]. Samples for solid and liquid carbon analysis and macro- and micronutrient analysis were collected at the end of the experiment to determine the increase of nutrient plant availability. The final carbon and nutrient analyses were conducted as described above in Section 2.2. The change in the aqueous concentration of a specific nutrient after AT was calculated using the following equation:

$$
\Delta \mathrm{M}_{\text {aqueous }}=\frac{\left[\mathrm{B}_{\text {aqueous }}\right] /\left[\mathrm{B}_{\text {total }}\right]}{\left[\mathrm{A}_{\text {aqueous }}\right] /\left[\mathrm{A}_{\text {total }}\right]}
$$

where $\Delta \mathrm{M}_{\mathrm{aqueous}}$ is the change in the percent of the total nutrient concentration that is in the aqueous fraction of the effluent. Additionally, $\left[\mathrm{A}_{\text {aqueous }}\right]$ is the concentration $(\mathrm{mg} / \mathrm{L})$ of a nutrient in the aqueous fraction in the untreated drum screen effluent, $\left[A_{\text {total }}\right]$ is the total nutrient concentration in the untreated drum screen effluent, in $\mathrm{mg} / \mathrm{L},\left[\mathrm{B}_{\text {aqueous }}\right]$ is the concentration $(\mathrm{mg} / \mathrm{L})$ of a nutrient in the aqueous fraction after $\mathrm{AT}$, and $\left[\mathrm{B}_{\text {total }}\right]$ is the total nutrient concentration after $\mathrm{AT}$, in $\mathrm{mg} / \mathrm{L}$.

\subsection{Statistical Analysis}

A one-way analysis of variance (ANOVA) in JMP Pro version 14.1 Statistical Software (SAS Institute, Cary, NC, USA) was used to determine if the temperature, DO, $\mathrm{pH}$, TSS, and ORP was statistically similar or different between AT reactors and the abiotic controls. A Tukey's honestly significant difference (HSD) test was used to evaluate if the replicate 
reactors were statistically similar or different from each other within the AT treatment and the abiotic control. A pooled $t$-test was used to test the significance of the differences in TOC, TN, and total $S$ concentrations and in the percent of each nutrient's total mass in the aqueous fraction of the effluent after treatment and to test the significance of the mean TSS concentration in the AT and abiotic control reactors after treatment. A $p$ value $<0.05$ was considered statistically significant for all analyses.

\section{Results}

\subsection{Feed and Effluent Nutrient Analysis}

The nutrient profile of the $40 \%$ protein, $10 \%$ lipid finfish feed is reported in Table 1. The initial effluent had a $\mathrm{pH}$, TSS concentration, and C:N ratio of 7.4, $1347 \mathrm{mg} / \mathrm{L}$, and 1.06, respectively. Macro- and micro-nutrient concentrations, and the associated aqueous and particulate fractions in the initial effluent, are reported in Table 2.

Table 1. Feed nutrient profile. The nutrient profile of Zeigler Bros. Inc., Finfish Silver, $40 \%$ protein, $10 \%$ lipid feed.

\begin{tabular}{ccccccccc}
\hline & & \multicolumn{9}{c}{ Macro-Nutrients } \\
Nutrient & & $\mathrm{N}^{*}$ & $\mathrm{P}^{*}$ & $\mathrm{~K}^{*}$ & $\mathrm{Ca}^{*}$ & $\mathrm{Mg}^{*}$ & $\mathrm{~S}^{+}$ & \\
Feed & & 6.44 & 0.97 & 0.96 & 1.17 & 0.14 & 1024 & \\
& & & \multicolumn{7}{c}{ Micro-Nutrients } \\
Nutrient & $\mathrm{Fe}^{+}$ & $\mathrm{Mn}^{+}$ & $\mathrm{B}^{+}$ & $\mathrm{Cu}^{+}$ & $\mathrm{Zn}^{+}$ & $\mathrm{Mo}^{+}$ & $\mathrm{Na}^{+}$ & $\mathrm{Al}^{+}$ \\
Feed & 209 & 91.8 & 5.9 & 46.5 & 89.6 & 4.13 & 2051 & 0 \\
\hline
\end{tabular}

${ }^{*}$ Reported as percent of total mass, ${ }^{\dagger}$ Reported as $\mathrm{mg} / \mathrm{kg}$.

Table 2. Effluent nutrient analysis. Total nutrient concentrations in the drum screen effluent collected from UNH KFRAG as a combination of the aqueous and particulate nutrient mass normalized to $1 \mathrm{~L}$ of effluent.

\begin{tabular}{cccc}
\hline Nutrient & Total Drum Screen Effluent $(\mathbf{m g} / \mathrm{L})$ & $\begin{array}{c}\text { Aqueous } \\
\mathbf{( \% )}\end{array}$ & $\begin{array}{c}\text { Particulate } \\
\mathbf{( \% )}\end{array}$ \\
\hline $\begin{array}{c}\text { TOC } \\
\text { Macro-nutrients }\end{array}$ & 151 & 18.83 & 81.17 \\
$\mathrm{~N}$ & 143 & & \\
$\mathrm{P}$ & 5.13 & 88.54 & 11.46 \\
$\mathrm{~K}^{\dagger}$ & 303 & 31.76 & 68.24 \\
$\mathrm{Ca}$ & 21.3 & 99.96 & 0.04 \\
$\mathrm{Mg}$ & 17.6 & 72.80 & 27.20 \\
$\mathrm{~S}$ & 23.2 & 96.93 & 3.07 \\
Micro-nutrients & & 99.61 & 0.39 \\
$\mathrm{Fe}$ & 1.78 & & \\
$\mathrm{Mn}$ & 0.16 & 87.74 & 12.26 \\
$\mathrm{Cu}$ & 0.15 & 80.43 & 19.57 \\
$\mathrm{Zn}$ & 0.74 & 80.04 & 19.96 \\
$\mathrm{Na}$ & 34.6 & 94.20 & 5.80 \\
\end{tabular}

${ }^{\dagger}$ Supplemented nutrient in KFRAG.

\subsection{Reactor Sample Analysis}

The mean \pm standard deviation (SD) of the temperature, $\mathrm{DO}$, and $\mathrm{pH}$ in the AT reactors and abiotic controls are shown in Table 3 . The change in TSS concentration over the entire study period is shown in Figure 2. The initial TSS concentration of the drum screen effluent was $1347 \mathrm{mg} / \mathrm{L}$. On day 15, the final mean \pm SD TSS concentration of the AT reactors and abiotic controls was reduced from the untreated effluent by $76.17 \pm 6.97 \%$ and $62.06 \pm 7.77 \%$, respectively ( $p=0.0028$ and $p=0.0052$, respectively). Replicate samples collected from the individual AT reactors showed no statistical significance in the differences between reactors for each of the $48 \mathrm{~h}$ interval measurements $(p=0.3549)$. The replicate samples collected from the individual abiotic control reactors did show statistically significant differences between the replicates throughout the $48 \mathrm{~h}$ interval measurements $(p=0.0261)$. 
Table 3. Reactor environmental conditions. The mean $\pm \mathrm{SD}$ of the temperature, $\mathrm{DO}$, and $\mathrm{pH}$ in the AT reactors and the abiotic control reactors during the study.

\begin{tabular}{cccc}
\hline Parameter & AT Reactors & Abiotic Controls & $\begin{array}{c}p \text {-Value between } \\
\text { Treatments }\end{array}$ \\
\hline Temperature $\left({ }^{\circ} \mathrm{C}\right)$ & $22.6 \pm 1.32$ & $23.4 \pm 1.17$ & $=0.0398$ \\
DO $(\mathrm{MG} / \mathrm{L})$ & $0.96 \pm 0.22$ & $4.1 \pm 1.04$ & $<0.0001$ \\
$\mathrm{pH}$ & $7.5 \pm 0.28$ & $7.3 \pm 0.13$ & $=0.0003$ \\
\hline
\end{tabular}

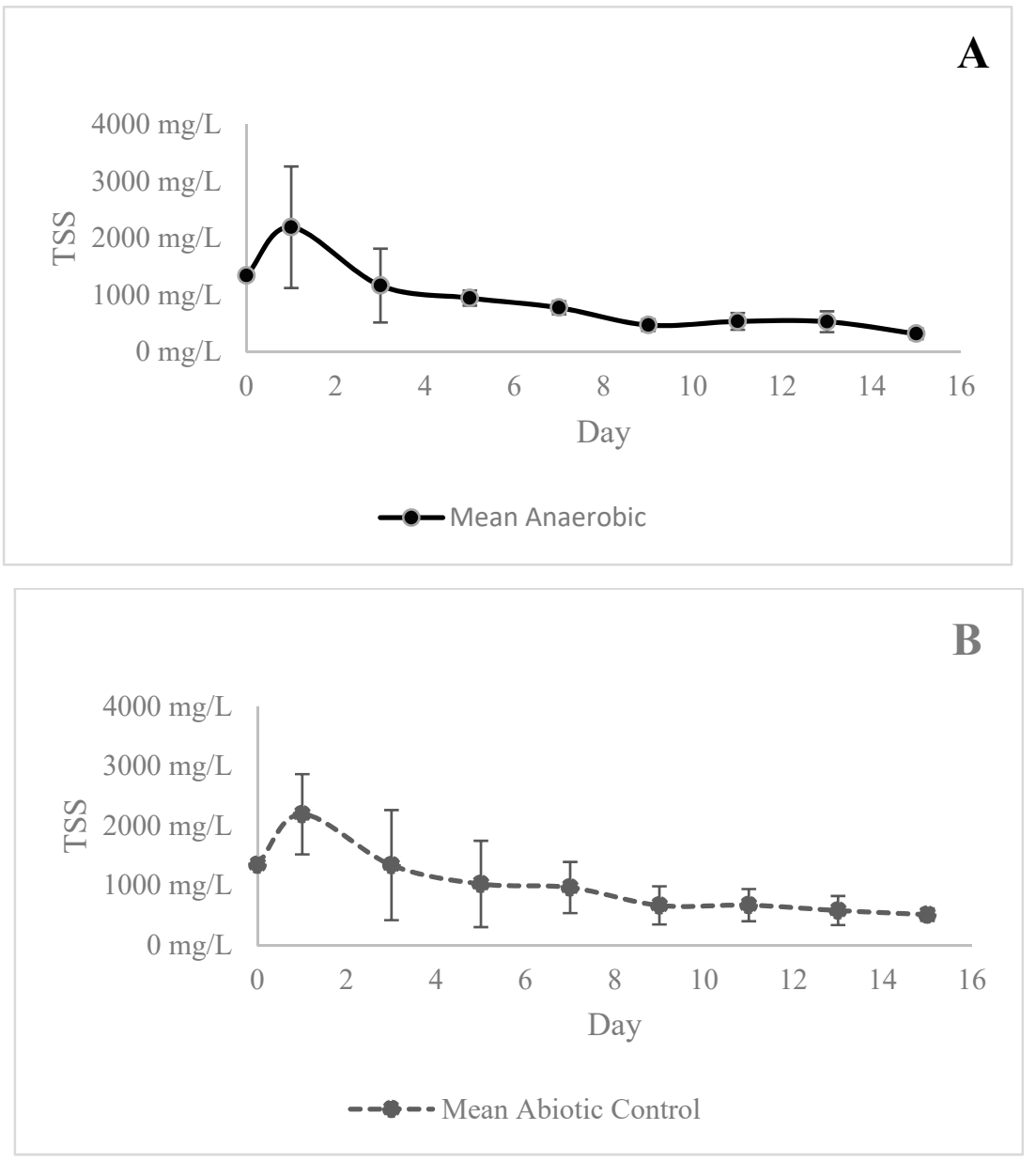

Figure 2. Reactor TSS concentrations. Mean TSS concentrations within AT treatment (A) and abiotic control (B) replicates throughout the 15-day study period. Error bars indicate standard deviation between treatment replicates.

The change in ORP in the AT reactors and abiotic controls is shown in Figure 3. The difference in the overall mean ORP in each of the AT replicate reactors was not statistically significant throughout the experiment $(p=0.9781)$. The ORP of the abiotic control replicates was not statistically significant throughout the experiment $(p=0.1782)$. The mean ORP in the AT reactors was significantly lower than the mean ORP in the abiotic controls $(p<0.0001)$. The ORP of each reactor used in this study was measured at the same time each TSS sample was taken. The linear regression line of the mean ORP and TSS concentrations had an $\mathrm{R}^{2}$ value of 0.94 (Figure 4 ). 


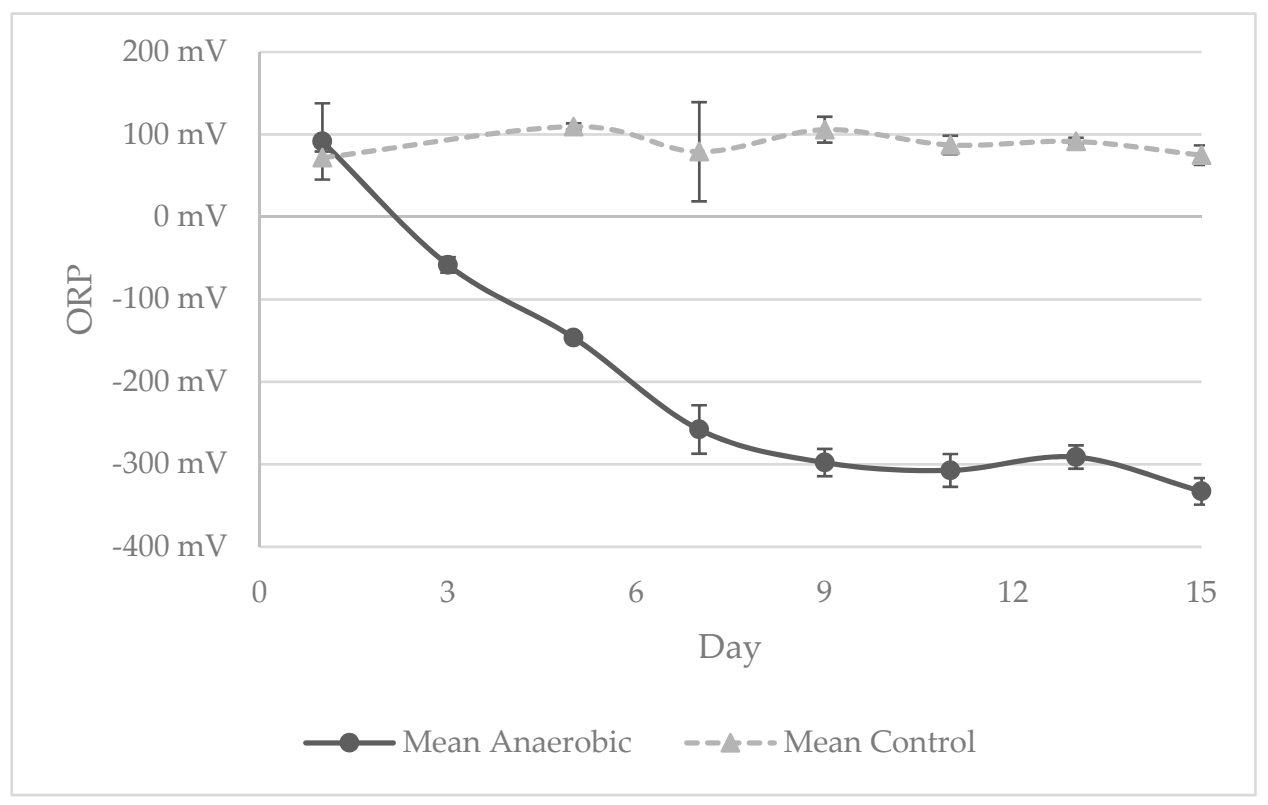

Figure 3. Reactor ORP. Mean ORP within the control (dash line) and anaerobic (solid line) replicates throughout the 15-day study period. Error bars indicate standard deviation between treatment replicates.

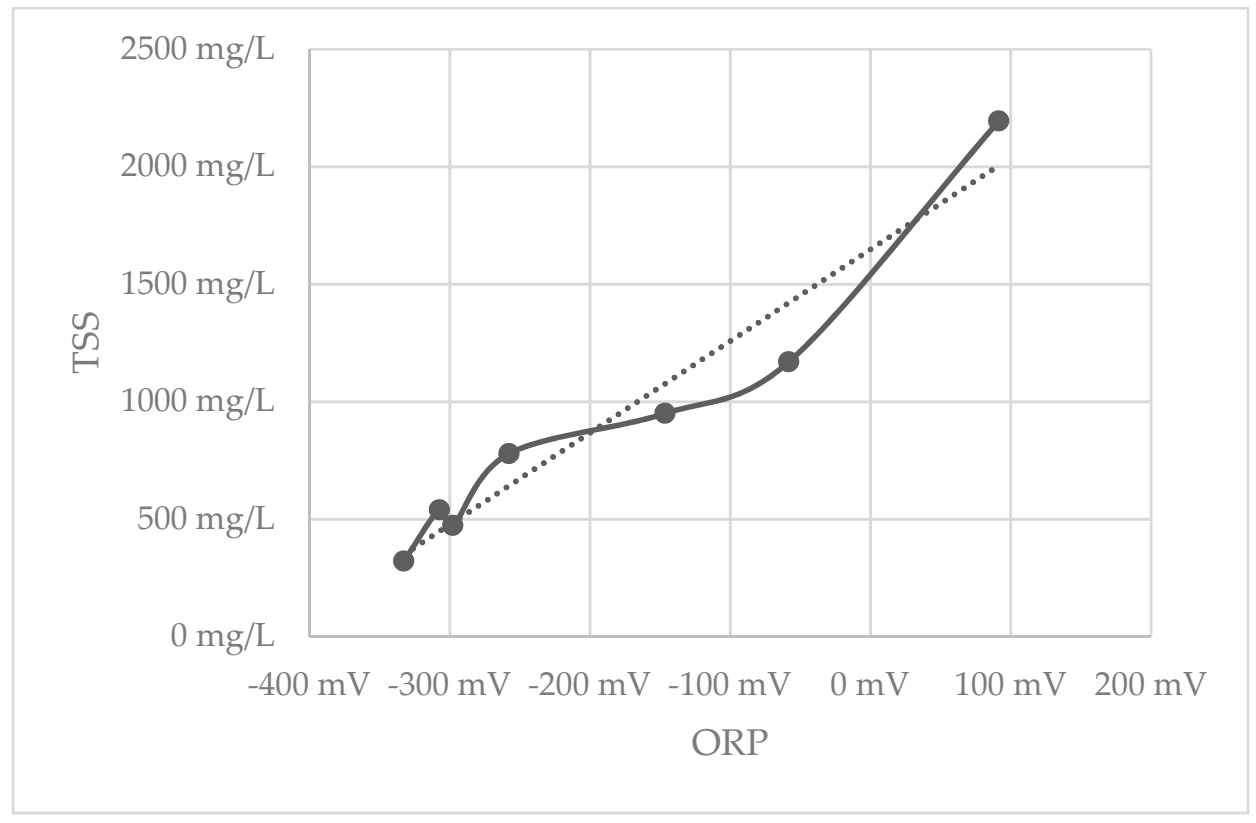

Figure 4. Correlation between ORP and TSS. The mean AT reactor TSS concentration plotted against the mean AT reactor ORP during the study period. The $\mathrm{R}^{2}$ value of the linear regression line is 0.94 .

\subsection{Carbon, Nitrogen, and Sulfur Mass Analysis}

The TOC, TN, and total S concentrations in the initial effluent and after treatment in the AT reactors and abiotic controls are shown in Figure 5. The final mean \pm SD of the TOC, TN, and total $\mathrm{S}$ concentrations in the AT reactors were significantly lower than the concentrations in the initial drum screen filter effluent ( $p=0.0030, p<0.0001, p<0.0001$, respectively). 


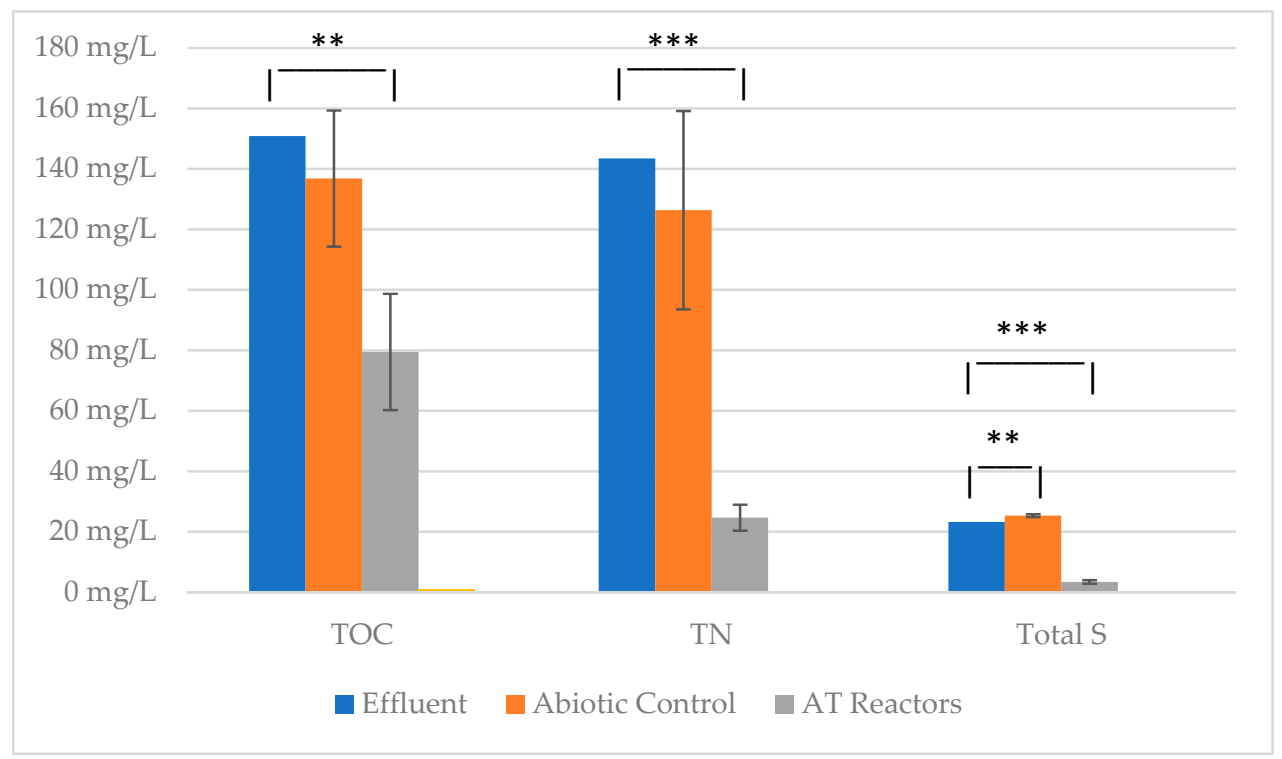

Figure 5. Nutrient reductions in AT reactors. The TOC, TN, and total S concentrations in the untreated drum screen effluent and after treatment in abiotic controls and AT reactors. Error bars indicate standard deviation, ${ }^{* *} p<0.01$, and ${ }^{* *} p<0.001$.

The difference in the final mean TOC and TN concentrations in the abiotic controls were not statistically significant from the initial drum screen effluent $(p=0.3408$ and $p=0.4179$, respectively). The final mean total $\mathrm{S}$ concentration was significantly greater than the initial effluent $(p=0.0015)$.

\subsection{Final Nutrient Analysis}

The change in the amount of the total nutrient concentration in the aqueous fraction of the treated effluent for TOC, N, P, Ca, Mg, Fe, Mn, and $\mathrm{Cu}$ are reported in Table 4. Although the TOC mass in the AT reactors were significantly lower after treatment (Figure 5), the percent of the remaining TOC in the aqueous fraction was significantly greater post treatment compared to the untreated effluent $(p=0.0004)$. The TN concentrations in the AT reactors were significantly lower after treatment (Figure 5). However, there was no statistical significance $(p=0.2125)$ in the percent of TN in the aqueous fraction between the AT treatments and untreated effluent. After AT, TN in the aqueous fraction of the effluent was comprised of $91.60 \%$ ammonia-nitrogen $\left(\mathrm{NH}_{4}-\mathrm{N}\right), 7.32 \%$ nitrate-nitrogen $\left(\mathrm{NO}_{3}-\mathrm{N}\right)$, and $1.08 \%$ urea.

After AT, the percent of total $\mathrm{P}$ and total Ca concentration dissolved in the aqueous portion of the effluent significantly increased $(p<0.0001$ and $p<0.0001$, respectively). The percent of the total $\mathrm{Fe}$ and $\mathrm{Mn}$ concentrations in the aqueous fraction of the effluent increased significantly after AT ( $p=0.0003$ and $p<0.0001$, respectively). The difference in the percent of the total $\mathrm{Cu}$ and $\mathrm{Zn}$ concentrations in the aqueous effluent fraction after AT was not statistically significant from the initial effluent ( $p=0.1628$ and $p=0.0696$, respectively).

The plant available concentration of macro- and micro-nutrients after AT is compared to the concentrations of the Jack's 5-12-26 Part A and Jack's 15-0-0 Calcium Nitrate Part B combined solution in Table 5. The relative ratios of each nutrient to $\mathrm{N}$ in the treated effluent and in the Jack's Part A and B combined solution is shown in Table 6. 
Table 4. AT reactor nutrient analysis. Percent change of nutrient concentrations in aqueous form (plant available) in the aquaponic tilapia effluent after AT. Mean percent \pm SD of total nutrients in aqueous form before and after anaerobic treatment are shown.

\begin{tabular}{ccc}
\hline Nutrient & $\begin{array}{c}\text { Initial Effluent } \\
\text { (\% Aqueous) }\end{array}$ & $\begin{array}{c}\text { Post-AT } \\
\text { (\% Aqueous) }\end{array}$ \\
\hline TOC & 18.83 & $86.36 \pm 10.8$ \\
Macro-nutrients & 88.54 & $93.83 \pm 4.23$ \\
$\mathrm{~N}$ & 31.76 & $99.53 \pm 0.20$ \\
$\mathrm{P}$ & 72.80 & $98.93 \pm 0.45$ \\
$\mathrm{Ca}$ & 96.93 & $99.78 \pm 0.07$ \\
$\mathrm{Mg}$ & & \\
Micro-nutrients & 87.74 & $98.91 \pm 1.58$ \\
$\mathrm{Fe}^{+}$ & 80.43 & $99.52 \pm 0.26$ \\
$\mathrm{Mn}$ & 80.04 & $91.61 \pm 11.7$ \\
$\mathrm{Cu}$ & 94.20 & $86.85 \pm 5.18$ \\
$\mathrm{Zn}$ & &
\end{tabular}

${ }^{\dagger}$ Supplemented nutrient in KFRAG.

Table 5. Hydroponics solution comparison. Plant available concentrations of nutrients after AT compared to recommended concentrations for hydroponic lettuce and leafy green production (fertilizer information retrieved from jrpeters.com, accessed on 15 October 2020).

\begin{tabular}{ccc}
\hline Nutrient & $\begin{array}{c}\text { Anaerobic } \\
(\mathbf{m g} / \mathbf{L})\end{array}$ & $\begin{array}{c}\text { Jack's Hydroponic } \\
(\mathbf{m g} / \mathrm{L})\end{array}$ \\
\hline Macro-nutrients & & \\
$\mathrm{N}$ & 23.1 & 150 \\
$\mathrm{P}$ & 5.11 & 39 \\
$\mathrm{~K}^{\dagger}$ & 303 & 162 \\
$\mathrm{Ca}$ & 21.1 & 139 \\
$\mathrm{Mg}$ & 17.6 & 47 \\
$\mathrm{~S}$ & 3.14 & $\mathrm{~N} / \mathrm{A}$ \\
Micro-nutrients & & \\
$\mathrm{Fe}$ & 1.8 & 2.3 \\
$\mathrm{Mn}$ & 0.16 & 0.38 \\
$\mathrm{Cu}$ & 0.137 & 0.113 \\
$\mathrm{Zn}$ & 0.74 & 0.11 \\
$\mathrm{Na}$ & 34.6 & $\mathrm{~N} / \mathrm{A}$ \\
\hline
\end{tabular}

${ }^{\dagger}$ Supplemented nutrient in KFRAG.

Table 6. Hydroponic solution ratio comparison. The plant available nutrient ratios of the untreated KFRAG effluent, the KFRAG effluent after AT, and a commercial hydroponic fertilizing solution on a ppm basis is shown. All nutrients are compared to N. Macro-nutrients (and Na) are normalized to $10 \mathrm{ppm}$ and micro-nutrients are normalized to $100 \mathrm{ppm}$.

\begin{tabular}{cccc}
\hline Nutrient & $\begin{array}{c}\text { Untreated Effluent } \\
(\mathbf{p p m})\end{array}$ & $\begin{array}{c}\text { AT } \\
\text { Reactors } \\
\text { (ppm) }\end{array}$ & $\begin{array}{c}\text { Jack's } \\
\text { Hydroponic } \\
\text { (ppm) }\end{array}$ \\
\hline Macro-nutrients & & & 10.0 \\
$\mathrm{~N}$ & 10.0 & 10.0 & 2.60 \\
$\mathrm{P}$ & 0.12 & 2.21 & 10.8 \\
$\mathrm{~K}^{+}$ & 22.3 & 131 & 9.27 \\
$\mathrm{Ca}$ & 1.14 & 9.13 & $\mathrm{~N} / \mathrm{A}$ \\
$\mathrm{S}$ & 1.70 & 1.36 & $\mathrm{~N} / \mathrm{A}$ \\
$\mathrm{Na}$ & & 15.0 & 1.53 \\
$\mathrm{Fe}{ }^{+}$ & 2.54 & 1.20 & 0.25 \\
$\mathrm{Mn}$ & 1.04 & 0.11 & 0.08 \\
$\mathrm{Cn}$ & 0.09 & 0.09 & 0.07 \\
\hline
\end{tabular}

${ }^{\dagger}$ Supplemented nutrient in KFRAG. 


\section{Discussion}

Increasing the mass of nutrients available through capture-and-reuse agricultural waste management methods has become increasingly important as the global scarcity of mined minerals is projected to have a detrimental impact on the agriculture industry in the coming decades [15,34]. This study focused on the treatment effects of AT for increasing the plant availability of nutrients and decreasing the organic carbon (OC) and TSS concentrations of aquaponic/RAS effluent as compared to an abiotic control. The removal of $\mathrm{OC}$ is required for any agricultural waste treatment method designed to repurpose the waste as a hydroponic fertilizing solution $[35,36]$.

\subsection{Feed and Drum Screen Effluent Nutrient Profiles}

The nutrient profile of the feed used would likely have a significant impact on the nutrient profile of the system effluent. The feed used in this study was chosen as it is commercially available and commonly used in the RAS industry. The drum screen effluent nutrient profile from KFRAG was similar to other reported aquaponic/RAS effluents $[24,25,37]$. In these previous studies, $\mathrm{P}, \mathrm{K}, \mathrm{Ca}, \mathrm{Mg}, \mathrm{Fe}, \mathrm{Mn}, \mathrm{Cu}$, and $\mathrm{Zn}$ were found to have a large percent of their total mass in the particulate fraction of the effluent, thus not immediately available for uptake by plants $[24,25,37]$. Excluding $K$, these were also the nutrients identified as the least plant available in the KFRAG drum screen effluent. Daily additions of soluble $\mathrm{K}_{2} \mathrm{CO}_{3}$ were made to the KFRAG systems for $\mathrm{pH}$ buffering and alkalinity adjustments for biofilter maintenance [38]. This increased the total mass and the plant availability of K at KFRAG compared to several other aquaponic/RAS facilities where effluent mineralization research was conducted [23-25]. While Fe was identified as a nutrient primarily bound in particulates in the KFRAG effluent, the percent of total Fe in the solid fraction of the KFRAG effluent was less than other facilities [23]. The routine additions of soluble DTPA Fe (III) at KFRAG resulted in an increased percent of the total Fe mass dissolved in the aqueous fraction of the effluent. It is important to note that the choice of $\mathrm{pH}$ buffering or fertilizing salts can affect the overall effluent nutrient profile in a given system and that the individual characterization of an aquaponic system is not necessarily representative of all system management approaches.

\subsection{Abiotic Controls Confirm Microbial Mineralization in AT Reactors}

The mean \pm SD of the DO, ORP, TOC, TN, and total $\mathrm{S}$ were significantly different between the abiotic controls and the AT reactors. These differences in reactor parameters confirmed that microbial activity was present and the cause of solids reduction and nutrient release in the AT reactors. While $\mathrm{NaN}_{3}$ was able to produce a similar degree of mineralization as AT through chemical reactions, its excessive sodium concentration and inhibition of cell growth eliminate it for use in the hydroponic industry [39]. It is also important to note that while the microbial and chemical properties of treatment exhibited by the AT and abiotic treatments, respectively, resulted in some similarities in terms of mineralization effects, the reduction of TOC concentration was distinctively unique to the microbial respiration in the AT treatment. The TOC concentration in the AT reactors was reduced by $47.42 \%$ after treatment, while the difference in the TOC concentration in the abiotic controls was not statistically significant (Figure 5). The $8.26 \%$ total S concentration increase from the initial effluent in the abiotic controls was assumed to be a sampling error from uneven mixing prior to analysis. Abiotic control reactors provided evidence through comparison that AT conditions were met and microbial activity occurred throughout the experiment in the AT reactors.

\subsection{AT Reactor Solids Reductions and Biological Activity}

The stabilization of the TSS concentration in the AT reactors was used as the metric for determining the time at which the mineralization of the particulates was effectively completed. The $76.17 \pm 6.97 \%$ reduction of the KFRAG effluent over 15 days was greater than the TSS reductions previously reported from a similar study on the AT of aquaponic 
effluent [24]. Delaide et al. [24] reported a 49.02\% TSS reduction in aquaponic tilapia effluent after AT with a 15 day hydraulic retention time (HRT). Sampling at $48 \mathrm{~h}$ intervals provided evidence that the majority of solids reduction occurs prior to day 15 , and a shorter HRT may be sufficient to achieve mineralization (Figure 2).

Biological reactions important to AT that can be monitored using ORP include denitrification and sulfide formation and fermentation [40]. Denitrification occurs at ORP values between +50 and $-50 \mathrm{mV}$ and sulfide formation occurs at ORP values between -50 and $-250 \mathrm{mV}[40,41]$. On day 3 , the ORP in the AT reactors was within the range for denitrification and sulfide production, with mean \pm SD measurements of $-58.2 \pm 9.43 \mathrm{mV}$ (Figure 3). On day 9, ORP in the AT reactors began to stabilize at $-298 \pm 16.6 \mathrm{mV}$, which was below the range for all relevant reactions to occur within the reactors (Figure 3 ). The ORP of AT reactors was not routinely reported in other published studies on the anaerobic treatment of aquaponic effluent for reuse as a hydroponic fertilizing solution [23-25].

The correlation between the reduction and stabilization of TSS concentrations with the reduction and stabilization of ORP measurements indicates that ORP stabilization can serve as a metric for determining when a specific AT reactor has achieved maximum mineralization and solids reductions (Figure 4).

\subsection{Treated Effluent Nutrient Profile}

While AT resulted in the solids reduction, TOC removal, and nutrient mineralization needed for reuse as a hydroponic fertilizer, the treated effluent also had significantly reduced concentrations of $\mathrm{N}$ and $\mathrm{S}$. Both are macro-nutrients required for plant growth and deficiencies in either nutrient can result in stunted growth and the disruption of physiological pathways $[39,42]$ (pp. 135-157). In plants, N serves a vital role in photosynthesis, and both $\mathrm{N}$ and $\mathrm{S}$ are primary components in proteins [39,42] (pp. 135-150). The form of $\mathrm{N}$ after AT must also be considered when evaluating the effluent for reuse as a hydroponic fertilizing solution. Prior to AT, the effluent from KFRAG had a plant available TN concentration of $127 \mathrm{mg} / \mathrm{L}$. Over $99 \%$ of the plant available TN in the untreated effluent was $\mathrm{NO}_{3}-\mathrm{N}$, the preferred form for uptake by hydroponic plants [43,44]. After AT, the mean plant available TN concentration of the effluent was $23.1 \mathrm{mg} / \mathrm{L}$ and comprised of $91.60 \%$ $\mathrm{NH}_{4}-\mathrm{N}, 7.32 \% \mathrm{NO}_{3}-\mathrm{N}$, and $1.08 \%$ urea. Additionally, $\mathrm{S}$ is often considered an overlooked element in fertilizers and many crops have been identified as sulfur deficient $[42,45,46]$. When evaluating the potential of using AT to develop a hydroponic nutrient solution, the reduction in total mass of $\mathrm{N}$ and $\mathrm{S}$ must be considered with the increased plant availability of other nutrients. As a means of estimating the effectiveness of the treated effluent as a fertilizing solution, the nutrient profile of the treated effluent was compared to nutrient recommendations for hydroponic lettuce and leafy green production (Table 5).

The plant availability of the nutrients was increased after AT. However, only the $\mathrm{K}, \mathrm{Cu}$, and $\mathrm{Zn}$ concentrations in the KFRAG effluent met or exceed the recommended concentrations for hydroponic lettuce and leafy green production after treatment (Table 5). It must also be noted that the concentrations of K and Fe are supplemented at KFRAG and the overall concentrations are not necessarily representative of other aquaponic facilities. In other studies on the nutrient profile of aquaponic effluent, $\mathrm{K}$ was shown to be present in lower concentrations and largely plant unavailable prior to treatment [23,25]. Similarly, the addition of soluble Fe salts increased the plant availability of Fe in the untreated effluent at KFRAG in comparison to other published studies [23,25]. While the mass and initial plant availability of Fe is not comparable between KFRAG and other aquaponic facilities, this study still demonstrated the ability of AT to significantly increase the plant availability of Fe in aquaponic effluent. The total concentration of each nutrient, not the plant availability of the nutrients, however, becomes the limiting factor for developing a hydroponic nutrient solution from aquaponic/RAS effluent through AT. Supplementation with traditional chemical fertilizers or concentration of the effluent is required to match nutrient concentration of the commercial solution. 
The relative ratios of nutrients between treated aquaponic/RAS effluent and commercial hydroponic fertilizing solutions must be evaluated when considering the potential of concentrating treated aquaponic/RAS effluent. The macro-nutrient ratios of the untreated KFRAG effluent were lower than the commercial solution and not ideal for plant production (Table 6). The nutrient ratios of the KFRAG effluent after AT are more comparable to the commercial solution than the untreated effluent (Table 6). This similarity between the nutrient ratios of the effluent after AT and the commercial solution is due largely to the TN reduction that balanced the ratio of $\mathrm{N}$ to the other macro-nutrients in the treated effluent.

Nutrient ratios of concern in the KFRAG effluent after AT are N:K and N:Na. Although $\mathrm{K}$ is an essential nutrient for plant growth, excess $\mathrm{K}$ can interfere with the uptake of other nutrients [47] (pp. 135-152). An increased K concentration was observed at KFRAG compared to other aquaponic/RAS facilities $[23,25]$. The high N:K ratio observed in the KFRAG effluent is unlikely to occur when a facility is not dosing daily with $\mathrm{K}_{2} \mathrm{CO}_{3}$. Few plants need $\mathrm{Na}$ for growth, and similar to excess $\mathrm{K}$, it can interfere with the uptake of required nutrients [34]. A hydroponic fertilizing solution containing excess Na could prevent plants from up-taking other nutrients. To maximize the potential of aquaponic/RAS effluent for reuse as a hydroponic fertilizing solution, the nutrient profile of anything added to the system must be considered in terms of how it will affect the effluent.

\subsection{Organic Carbon Removal}

The presence of OC could limit the adoption of treated aquaponic/RAS effluent as a hydroponic fertilizing solution regardless of increased plant availability and solids reduction. In a hydroponic system, OC build-up can result in detrimental effects to both the physical and physiological health of plants [35,48]. Heterotrophic bacteria feed on OC and can colonize into biofilms that physically disrupt irrigation water flow in a hydroponic system, consume DO in the root zone, and outcompete plants for nutrient uptake. Many heterotrophic bacteria are also pathogenic and can cause disease in crops and humans [48]. Beyond disruption of system operation and potential food safety concerns, OC has also been shown to have phytotoxic effects that reduce plant growth by negatively altering physiological functions $[35,49]$.

The AT reactors used in this study reduced the mean \pm SD TOC concentration of the KFRAG effluent by $47.42 \pm 12.76 \%$ (Figure 5). This reduction is comparable to TOC reductions in other waste streams by AT and to the organic matter reduction reported in another study on the AT of aquaponic effluent [24]. The portion of the TOC concentration remaining after treatment that was dissolved in the aqueous fraction of the effluent was increased from $18.83 \%$ to $86.36 \pm 10.8 \%$ (Table 4 ). Based on the results of this study, the DOC concentration increased from $28.4 \mathrm{mg} / \mathrm{L}$ to $68.6 \mathrm{mg} / \mathrm{L}$ as a result of AT. This study showed that AT can significantly increase the plant availability of nutrients and significantly reduce the TSS and TOC concentration of aquaponic effluent. However, AT also dissolved most of the remaining OC in the effluent, leading to a greater concentration of DOC after treatment than in the untreated effluent. While AT is a promising initial treatment option to increase nutrient availability and reduce solids, a secondary treatment process is required to remove remaining DOC before the effluent can become a viable hydroponic fertilizing solution.

\subsection{Future Research for Improved Treatment}

Consideration should be given regarding the economic feasibility and the by-products of anaerobically treating RAS effluent for reuse as a nutrient solution. Aquaponic farms producing both fish and hydroponic plants are well suited for on-site treatment and reuse, but cost-benefit analysis research is required for solely RAS operations that would treat and ship the effluent as sellable product. Crystallization of aqueous nutrient salts is currently being explored in the terrestrial animal agriculture industry to create highly concentrated and fully soluble fertilizers, prevent eutrophication as a result of runoff, and end reliance on finite mineral reserves $[46,50]$. This is promising research that could be adopted for 
treated RAS effluent that has an ideal hydroponic nutrient ratio, but limited resale value due to transportation costs from a RAS to a hydroponic farm. Additionally, increasing the scale of RAS effluent AT to meet the commercial industry would first require research into the generation and capture of the GHGs produced during treatment [51,52]. Several GHGs, including $\mathrm{CH}_{4}$ and $\mathrm{H}_{2}$, are a byproduct of AT [52,53]. Incorporating existing technologies from terrestrial agriculture GHG sequestration and biofuel production would eliminate pollution and provide another value-added product from the AT RAS effluent $[52,53]$.

Microbial community characterization and temperature optimization provide the potential to increase the rate and degree of nutrient mineralization in AT [26,54,55]. Anaerobic microbial communities are complex, with many species functioning most efficiently at specific environmental parameters [55]. Identifying the specific anaerobes involved in the AT of RAS effluent may allow the adoption of species-specific environmental conditions to increase treatment efficiency. Similar to the variety of microbial species involved, a wide range of temperatures can be used for AT [54,56,57]. Two commonly used temperatures for domestic wastewater treatment are mesophilic $\left(35^{\circ} \mathrm{C}\right)$ and thermophilic $\left(55^{\circ} \mathrm{C}\right)[54,56,57]$. Hydrolysis has been identified as one of the slowest reactions to occur during AT [21]. Ge et al. [54] found that the hydrolysis rate in AT was nearly doubled when the reactor temperature was increased from $38{ }^{\circ} \mathrm{C}$ to $55{ }^{\circ} \mathrm{C}$. However, the same study also determined that fermentation and glucose consumption occurred more rapidly at $38^{\circ} \mathrm{C}$ than $55^{\circ} \mathrm{C}$ [54]. Both the initial breakdown of large organic matter during hydrolysis and the mineralization of smaller particles during fermentation are vital to the treatment of RAS effluent. Further research dedicated to either identifying an optimal middle temperature to better facilitate both processes in a batch reactor or developing a multi-stage reactor with different temperature ranges could increase the AT rate of aquaponic/RAS effluent. While increasing temperature from the ambient range used for the AT of KFRAG effluent may increase mineralization rate, the cost of reactor heating must also be considered against the decrease in reaction time [58].

Aerobic methods are often used as a finishing process for wastes treated anaerobically $[59,60]$. During aerobic digestion, organic matter is broken down and oxidized into $\mathrm{CO}_{2}$ in a constantly aerated system [61] (pp. 38-54). Aerobic digestion can achieve greater organic matter reduction in both industrial and aquaponic/RAS effluent treatment than anaerobic $[24,59]$. Sludge production from microbial growth and high treatment costs due to constant aeration are often limiting factors for the large-scale application of aerobic digestion [62]. However, multiple studies have shown greater than $90 \%$ COD reduction when aerobic digestion is used as a finishing process after AT has reduced the solids content of a waste stream and performed initial OC reduction [59,60]. An additional benefit of adding an aerobic treatment after the AT of aquaponic/RAS effluent is nitrification to convert $\mathrm{NH}_{4}-\mathrm{N}$ to $\mathrm{NO}_{3}-\mathrm{N}$ for improved plant growth performance [40,43]. Research on the incorporation of an aerobic stage after AT could enhance aquaponic/RAS effluent treatment and result in a final solution with reduced OC concentrations and the majority of $\mathrm{TN}$ in the ideal form for uptake by hydroponic plants $[43,60]$.

\section{Conclusions}

This study confirmed that AT reduced the TSS and TOC concentration of aquaponic/RAS drum screen effluent and simultaneously increased the plant availability of the nutrients. Additional data collected identified a strong correlation between the reduction and stabilization of TSS concentrations and the reduction and stabilization of ORP measurements throughout the treatment process within the AT reactors. Based on this correlation, ORP stabilization can provide an accurate assessment of when a specific AT reactor has achieved maximum solids reduction and nutrient mineralization. Certain limitations of this study that could be improved in future research in this area include increased replication of the untreated effluent water quality and analysis of source water to account for the presence of trace system nutrients not supplied by fish feed or intentionally added sources. Future research would benefit from conducting a further characterization of the untreated effluent. 
Although the scope of this work was limited due to these factors, it clearly demonstrated that AT reduces total solids content, mineralizes particulate bound nutrients, and removes TOC from RAS effluent.

After treatment, the nutrient ratios in the effluent were more comparable to the nutrient ratios of a commercially available hydroponic fertilizing solution than the untreated effluent. This is promising progress towards a treatment system for the development of a naturally derived nutrient solution from aquaponic/RAS effluent. The increased DOC concentration after AT makes the treated effluent unsuitable for use as a hydroponic fertilizing solution due to the negative effects that OC has on hydroponic production $[35,48]$. While AT can provide initial treatment to reduce solids and mineralize nutrients, a second stage of treatment is required to further remove OC before aquaponic/RAS effluent can be reused as a hydroponic fertilizing solution. A finishing stage of aerobic digestion is often used on AT effluent to remove additional OC. Future research on the continued treatment of aquaponic/RAS effluent using aerobic digestion is needed to continue the development of a naturally derived nutrient solution. Maximizing the plant availability of aquaponic/RAS effluent in lab-scaled batch reactors is the first step to developing a treatment system for commercial operations. As the scale of treatment increases, additional consideration must also be given to the production and capture of non-target gases to avoid excessive emissions of GHGs and to the cost-benefit analysis of treating and resale costs for RAS farmers not reusing treated solutions onsite.

Author Contributions: Conceptualization, J.T. and T.G.; methodology, J.T. and T.G.; validation, J.T.; formal analysis, J.T. and T.G.; investigation, J.T.; resources, J.T. and T.G.; data curation, J.T.; writing—original draft preparation, J.T.; writing—review and editing, J.T., T.G., and R.F.; visualization, J.T., R.F., and T.G.; supervision, J.T.; project administration, J.T.; funding acquisition, T.G. and R.F. All authors have read and agreed to the published version of the manuscript.

Funding: This work was funded in part by a grant from New Hampshire Sea Grant, Project R/SFA-8, pursuant to National Oceanic and Atmospheric Administration Award No. NA18OAR4170090. Partial funding was provided by the New Hampshire Agricultural Experiment Station (Scientific Contribution Number NH00648). This work was supported by the USDA National Institute of Food and Agriculture Hatch Project (1010110).

Institutional Review Board Statement: Not applicable.

Informed Consent Statement: Not applicable.

Data Availability Statement: The tables and figures report the data collected in this study. Any data not reported in this study is available on request from the corresponding author. Data was not made immediately publicly available as it is being used in additional manuscripts not yet publish.

Conflicts of Interest: The authors declare no conflict of interest.

\section{References}

1. Van Rijn, J. The potential for integrated biological treatment systems in recirculating fish culture-A review. Aquacultue 1996, 139, 181-201. [CrossRef]

2. Gelfand, I.; Barak, Y.; Even-Chen, Z.; Cytryn, E.; van Rijn, J.; Krom, M.D.; Neori, A. A Novel Zero Discharge Intensive Seawater Recirculating System for the Culture of Marine Fish. J. World Aquac. Soc. 2003, 34, 344-358. [CrossRef]

3. Timmons, M.; Guerdat, T.; Vinci, B.J. Recirculating Aquaculture, 4th ed.; Ithaca Publishing Company, LLC: Vero Beach, FL, USA, 2018; pp. 2-25.

4. Miller, D.; Semmens, K. Waste Management in Aquaculture. Aquaculture 2002, 1-10. Available online: https: / / freshwater-aquaculture. extension.org/wp-content/uploads/2019/08/WasteManagemetninAquaculture.pdf (accessed on 14 December 2020).

5. EPA (United States Environmental Protection Agency). Effluent Limitations Guidelines and New Source Performance Standards for the Concentrated Aquatic Animal Production Point Source Category; Final Rule. 40 CFR Part 451; EPA: Washington, DC, USA, 2004.

6. Sharrer, M.; Rishel, K.; Taylor, A.; Vinci, B.J.; Summerfelt, S.T. The cost and effectiveness of solids thickening technologies for treating backwash and recovering nutrients from intensive aquaculture systems. Bioresour. Technol. 2010, 101, 6630-6641. [CrossRef]

7. Tsani, S.; Koundouri, P. A Methodological Note for the Development of Integrated Aquaculture Production Models. Front. Mar. Sci. 2018, 4, 406. [CrossRef] 
8. Goddek, S.; Delaide, B.; Mankasingh, U.; Ragnarsdottir, K.V.; Jijakli, H.; Thorarinsdottir, R. Challenges of Sustainable and Commercial Aquaponics. Sustainability 2015, 7, 4199-4224. [CrossRef]

9. Delaide, B.; Goddek, S.; Gott, J.; Soyeurt, H.; Jijakli, M.H. Lettuce (Lactuca sativa L. var. Sucrine) Growth Performance in Complemented Aquaponic Solution Outperforms Hydroponics. Water 2016, 8, 467. [CrossRef]

10. Bhatt, A.H.; Tao, L. Economic Perspectives of Biogas Production via Anaerobic Digestion. Bioengineering 2020, 7, 74. [CrossRef]

11. Caruso, M.C.; Braghieri, A.; Capece, A.; Napolitano, F.; Romano, P.; Galgano, F.; Altieri, G.; Genovese, F. Recent Updates on the Use of Agro-Food Waste for Biogas Production. Appl. Sci. 2019, 9, 1217. [CrossRef]

12. Bhatt, A.H.; Ren, Z.J.; Tao, L. Value Proposition of Untapped Wet Wastes: Carboxylic Acid Production through Anaerobic Digestion. iScience 2020, 23, 101221. [CrossRef]

13. Lee, U.; Benavides, P.T.; Wang, M. Waste-To-Energy: Multi-Criteria Decision Analysis for Sustainability Assessment and Ranking; Academic Press: Cambridge, MA, USA, 2020; pp. 213-233.

14. Schneider, O.; Sereti, V.; Eding, E.H.; Verreth, J.A.J. Analysis of nutrient flows in integrated intensive aquaculture systems. Aquac. Eng. 2005, 32, 379-401. [CrossRef]

15. Henckens, M.L.C.M.; van Ierland, E.; Driessen, P.P.J.; Worrell, E. Mineral resources: Geological scarcity, market price trends, and future generations. Resour. Policy 2016, 49, 102-111. [CrossRef]

16. Yogev, U.; Sowers, K.R.; Mozes, N.; Gross, A. Nitrogen and carbon balance in a novel near-zero water exchange saline recirculating aquaculture system. Aquaculture 2017, 467, 118-126. [CrossRef]

17. Goddek, S.; Joyce, A.; Kotzen, B.; Burnell, G. Aquaponics Food Production Systems: Combined Aquaculture and Hydroponic Production Technologies for the Future; Springer Open: Berlin/Heidelberg, Germany, 2019; pp. 247-266.

18. Chen, Y.; Cheng, J.J.; Creamer, K.S. Inhibition of anaerobic digestion process: A review. Bioresour. Technol. 2008, 99, 4044-4064. [CrossRef]

19. Parkin, G.F.; Owen, W.F. Fundamentals of Anaerobic Digestion of Wastewater Sludges. J. Environ. Eng. 1986, 112, 867-920. [CrossRef]

20. Fan, Y.V.; Klemeš, J.J.; Lee, C.T.; Perry, S. Anaerobic digestion of municipal solid waste: Energy and carbon emission footprint. J. Environ. Manag. 2018, 223, 888-897. [CrossRef]

21. Ma, J.; Frear, C.; Wang, Z.-W.; Yu, L.; Zhao, Q.; Li, X.; Chen, S. A simple methodology for rate-limiting step determination for anaerobic digestion of complex substrates and effect of microbial community ratio. Bioresour. Technol. 2013, 134, 391-395. [CrossRef]

22. Anukam, A.; Mohammadi, A.; Naqvi, M.; Granström, K. A Review of the Chemistry of Anaerobic Digestion: Methods of Accelerating and Optimizing Process Efficiency. Processes 2019, 7, 504. [CrossRef]

23. Goddek, S.; Delaide, B.P.; Joyce, A.; Wuertz, S.; Jijakli, M.H.; Gross, A.; Eding, E.H.; Bläser, I.; Reuter, M.; Keizer, L.P.; et al. Nutrient mineralization and organic matter reduction performance of RAS-based sludge in sequential UASB-EGSB reactors. Aquac. Eng. 2018, 83, 10-19. [CrossRef]

24. Delaide, B.; Goddek, S.; Keesman, K.J.; Jijakli, M.H.M. A methodology to quantify the aerobic and anaerobic sludge digestion performance for nutrient recycling in Aquaponics. Biotechnol. Agron. Soc. Environ. 2018, 22, 106-112. [CrossRef]

25. Monsees, H.; Keitel, J.; Paul, M.; Kloas, W.; Wuertz, S. Potential of aquacultural sludge treatment for aquaponics: Evaluation of nutrient mobilization under aerobic and anaerobic conditions. Aquac. Environ. Interact. 2017, 9, 9-18. [CrossRef]

26. Conroy, J.; Couturier, M. Dissolution of minerals during hydrolysis of fish waste solids. Aquaculture 2010, 298, 220-225. [CrossRef]

27. Losordo, T.M.; Hobbs, A.O.; DeLong, D.P. The design and operational characteristics of the CP\&L/EPRI fish barn: A demonstration of recirculating aquaculture technology. Aquac. Eng. 2000, 22, 3-16. [CrossRef]

28. DeLong, D.; Losordo, T.; Rakocy, J. Tank Culture of Tilapia; Southern Regional Aquaculture Center: Stoneville, MS, USA, 2009.

29. Mattson, N.; Peters, C. A Recipe for Hydroponic Success. Inside Grower, January 2014; pp. 16-19. Available online: https: / / dokumen.tips/documents / a-recipe-for-hydroponic-successpdf.html (accessed on 14 December 2020).

30. Standard Methods. Standard Methods for the Examination of Water and Wastewater, 19th ed.; American Public Health Association: Washington, DC, USA, 2012; pp. 2-71.

31. Merriam, J.; McDowell, W.H.; Currie, W.S. A High-Temperature Catalytic Oxidation Technique for Determining Total Dissolved Nitrogen. Soil Sci. Soc. Am. J. 1996, 60, 1050-1055. [CrossRef]

32. Barbot, E.; Seyssiecq, I.; Roche, N.; Marrot, B. Inhibition of activated sludge respiration by sodium azide addition: Effect on rheology and oxygen transfer. Chem. Eng. J. 2010, 163, 230-235. [CrossRef]

33. Cioabla, A.E.; Ionel, I.; Dumitrel, G.-A.; Popescu, F. Comparative study on factors affecting anaerobic digestion of agricultural vegetal residues. Biotechnol. Biofuels 2012, 5, 39. [CrossRef] [PubMed]

34. Cordell, D.; Drangert, J.-O.; White, S. The story of phosphorus: Global food security and food for thought. Glob. Environ. Chang. 2009, 19, 292-305. [CrossRef]

35. Lee, J.G.; Lee, B.Y.; Lee, H.J. Accumulation of phytotoxic organic acids in reused nutrient solution during hydroponic cultivation of lettuce (Lactuca sativa L.). Sci. Hortic. 2006, 110, 119-128. [CrossRef]

36. Furtner, B.; Bergstrand, K.J.; Brand, T.; Jung, V.; Alsanius, B.W. Abiotic and biotic factors in slow filters integrated to closed hydroponic systems. Eur. J. Hortic. Sci. 2007, 72, 104-112.

37. Guerdat, T.C.; Losordo, T.M.; Delong, D.P.; Jones, R.D. An evaluation of solid waste capture from recirculating aquaculture systems using a geotextile bag system with a flocculant-aid. Aquac. Eng. 2013, 54, 1-8. [CrossRef] 
38. Anderson, T. Biological Responses of Lettuce to Hydroponic and Aquaponic Conditions. Master's Thesis, Cornell University, Ithaca, NY, USA, 2016.

39. Marschner, H. Mineral Nutrition of Higher Plants, 3rd ed.; Academic Press: Cambridge, MA, USA, 2011; pp. 135-150, 151-157.

40. Gerardi, M. ORP Management in Wastewater as an Indicator of Process Efficiency; Interstate Water Report; NEIWPCC: Lowell, MA, USA, 2007.

41. Dabkowski, B. Applying Oxidation Reduction Potential Sensors in Biological Nutrient Removal Systems. Proc. Water Environ. Fed. 2008, 2008, 3033-3042. [CrossRef]

42. Etienne, P.; Sorin, E.; Maillard, A.; Gallardo, K.; Arkoun, M.; Guerrand, J.; Cruz, F.; Yvin, J.-C.; Ourry, A. Assessment of Sulfur Deficiency under Field Conditions by Single Measurements of Sulfur, Chloride and Phosphorus in Mature Leaves. Plants 2018, 7, 37. [CrossRef]

43. Ikeda, H.; Osawa, T. Nitrate- and Ammonium-N Absorption by Vegetables from Nutrient Solution Containing Ammonium Nitrate and the Resultant Change of Solution pH. J. Jpn. Soc. Hortic. Sci. 1981, 50, 225-230. [CrossRef]

44. Shinohara, M.; Aoyama, C.; Fujiwara, K.; Watanabe, A.; Ohmori, H.; Uehara, Y.; Takano, M. Microbial mineralization of organic nitrogen into nitrate to allow the use of organic fertilizer in hydroponics. Soil Sci. Plant Nutr. 2011, 57, 190-203. [CrossRef]

45. Gilbert, F.A. The place of sulfur in plant nutrition. Bot. Rev. 1951, 17, 671-691. [CrossRef]

46. Zhang, T.; Jiang, R.; Deng, Y. Phosphorus Recovery by Struvite Crystallization from Livestock Wastewater and Reuse as Fertilizer: A Review. Phys. Chem. Wastewater Treat. Resour. Recovery 2017, 135-152. [CrossRef]

47. Cooil, B.; Slattery, M. Effects of potassium deficiency and excess upon certain carbohydrate and nitrogenous con-stituents in guayule1. Plant Physiol. 1948, 234, 425-442. [CrossRef]

48. Yaron, S.; Römling, U. Biofilm formation by enteric pathogens and its role in plant colonization and persistence. Microb. Biotechnol. 2014, 7, 496-516. [CrossRef]

49. Garland, J.L.; Mackowiak, C.L.; Strayer, R.F.; Finger, B.W. Integration of waste processing and biomass production systems as part of the KSC Breadboard project. Adv. Space Res. 1997, 20, 1821-1826. [CrossRef]

50. Schooley, K.; Bourgier, V.; Lawson, R. Evaporation and Crystallisation Challenges. World Fertilizer, 2017. Available online: https:/ / www.cabdirect.org/cabdirect/abstract/20163275073 (accessed on 14 December 2020).

51. Hamelin, L.; Naroznova, I.; Wenzel, H. Environmental consequences of different carbon alternatives for increased manure-based biogas. Appl. Energy 2014, 114, 774-782. [CrossRef]

52. Hamelin, L.; Wesnæs, M.; Wenzel, H.; Petersen, B.M. Environmental Consequences of Future Biogas Technologies Based on Separated Slurry. Environ. Sci. Technol. 2011, 45, 5869-5877. [CrossRef]

53. Gunaseelan, V.N. Anaerobic digestion of biomass for methane production: A review. Biomass Bioenergy 1997, 13, 83-114. [CrossRef]

54. Ge, H.; Jensen, P.D.; Batstone, D.J. Relative kinetics of anaerobic digestion under thermophilic and mesophilic conditions. Water Sci. Technol. 2011, 64, 848-853. [CrossRef] [PubMed]

55. Venkiteshwaran, K.; Bocher, B.; Maki, J.; Zitomer, D. Relating Anaerobic Digestion Microbial Community and Process Function: Supplementary Issue: Water Microbiology. Microbiol. Insights 2015, 8, 37-44. [CrossRef] [PubMed]

56. Bergland, W.H.; Dinamarca, C.; Bakke, R. Temperature Effects in Anaerobic Digestion Modeling. In Proceedings of the 56th Conference on Simulation and Modelling (SIMS 56), Linköping, Sweden, 7-9 October 2015; pp. 261-269.

57. Gebreeyessus, G.D.; Jenicek, P. Thermophilic versus Mesophilic Anaerobic Digestion of Sewage Sludge: A Comparative Review. Bioengineering 2016, 3, 15. [CrossRef]

58. Ruffino, B.; Campo, G.; Genon, G.; Lorenzi, E.; Novarino, D.; Scibilia, G.; Zanetti, M. Improvement of anaerobic digestion of sewage sludge in a wastewater treatment plant by means of mechanical and thermal pre-treatments: Performance, energy and economical assessment. Bioresour. Technol. 2015, 175, 298-308. [CrossRef] [PubMed]

59. Borzacconi, L.; López, I.; Ohanian, M.; Viñas, M. Anaerobic-Aerobic Treatment of Municipal Solid Waste Leachate. Environ. Technol. 1999, 20, 211-217. [CrossRef]

60. Del Pozo, R.; Diez, V. Organic matter removal in combined anaerobic-aerobic fixed-film bioreactors. Water Res. 2003, 37, 3561-3568. [CrossRef]

61. Maier, R.; Pepper, I.; Gerba, C. Environmental Microbiology, 2nd ed.; Academic Press: Cambridge, MA, USA, 2009 ; pp. 38-54.

62. Mata-Alvarez, J.; Macé, S.; Llabrés, P. Anaerobic digestion of organic solid wastes. An overview of research achievements and perspectives. Bioresour. Technol. 2000, 74, 3-16. [CrossRef] 